\title{
Cultural Preservation: Rediscovering the Endangered Oral Tradition of Maluku (A Case Study on Kapata of Central Maluku)
}

Fathu Rahman*, Prihe Slamatin Letlora

Hasanuddin University, Indonesia

Corresponding Author: Fathu Rahman, E-mail: fathu.rahman@unhas.ac.id

\section{ARTICLE INFO}

Article history

Received: December 19, 2017

Accepted: March 02, 2018

Published: April 30, 2018

Volume: 9 Issue: 2

Advance access: March 2018

Conflicts of interest: None

Funding: None

\section{Key words:}

Culture,

Language,

Folksong,

Oral Literature,

Tradition,

Endangered Traditions

\begin{abstract}
Language and culture are two aspects which interchange each other where the language is a medium to get information about the culture. As the product of language and culture, oral tradition plays a vital role in Maluku not only as the most powerful and sacred chant that regulate the life of people but also as the folk song that contains history, advice, and prayer. Kapata nowadays is assumed as the endangered oral traditions in Maluku. To rediscover the endangered oral traditions, descriptive qualitative research by using interview and library study in gaining the supporting information was implemented. Furthermore, this research was aimed (1) to figure out the history of Kapata and the way to preserve it (2) to map out the categories of Kapata and its function in social life, and (3) to elaborate the meaning of language expression conveyed in Kapata. Through this research, it is hoped that Kapata can be preserved by implementing it in formal education, art performance and framing in an advanced documentation so that all generations of Maluku are able to not only to recognize and make use it in social life as the way to preserve the Kapata as an endangered oral tradition.
\end{abstract}

\section{INTRODUCTION}

Language and culture are two important elements which cannot be separated each other. Language is a medium of communication to acquire the information of culture and others. Thus, humans are gifted to convey the message and to communicate one another by using language. Moreover, language is a part of the culture and both language and culture must be maintained. Culture is formed from the way people think and behave. From the way of thinking and behavior is formed a tradition of a culture that is different from one group with other community groups.

On the other hand, in a contemporary variant, the culture is defined as a social domain which underlines the practices, discourses, and material expressions, that express the continuities and discontinuities of the social meaning of a life held in common. Otherwise, culture also determines as the group of human activities including history, knowledge, basifies, arts, and morals as well as other traditions (Taylor in Latupapua, 2012). Further, culture generally consists of folksong, dances, games, and folklore that basically are determined as the living expression, developed and became famous in particular local ethnic. In line with this idea, Surya (2017: 508) stated that many ethnic groups have inherited the collection of folklore from generation to generation. As a product of language and culture, literature determines as human activities in particular media and have particular aesthetic characteristics as well (Taylor in Latupapua, 2012). Therefore it can be concluded that literature has a high potential to represent human cultures. Speaking of literature, it is divided into two main parts which are oral literature and written literature (Teeuw, 1994). The main difference between them is the medium which is determining transformation process in society. Oral literature is a form of literature that has been practiced in human civilization. It uses utterances or verbal language as the media so it can be said that the communication strategies used in the process are direct communication. In the other side, written literature uses written media. It appeared in the early century when human firstly begun to recognize and to use alphabet and symbols in the way of communicating, therefore writing has become a medium in literature communication between creator and the audience (Teeuw, 1994).

The term 'oral tradition' refers to a process and a result of the process. Oral traditions have become the substantial media to any societal community and cultural communication (Rahman, 2017). The result is in the form of oral messages based on the previous messages and at least one-aged 
generation. The process is the message delivery through mouth to mouth during several times until the messages are disappearing. Therefore, every oral tradition is a version in one moment, an element in an oral development process that begun by the early communication. Every time a human speaks, the messages can be produced, where some of the messages might be repeated and begin to start a message delivery process. The unlimited numbers from the various situations that support a human speaks to other human and to repeat the previous talk; it cannot be simplified into a classification (Vansina, 1985). Meanwhile, the delivered messages over generations become the oral tradition among the tradition there are many different classes rely on the extent evolution. The first class includes the memorized messages and in this class we can differ a daily language messages (spellings, prayers) the messages in poems. During the times, the memorized tradition possesses the different characteristics compare to the other traditions. Nowadays, we can differentiate the formal language (poem) and daily language (narration). A story (narration) is a part of two different classes based on its factuality criteria. Tradition or factual information is delivered with a different way - the contents are told closely to reality or fact - compare to fictive information as tales, proverbs or proverbial words (Vansina, 1985).

Maluku has diversity in culture specifically in oral tradition. There are three well-known oral traditions which are Kapata in Central Maluku, Tiarka in Southwest Maluku and Foruk in Southeast Maluku that contains traditional utterances that present with rhythm and the sounds of Tifa and Tahuri as the main musical instruments. Kapata, Tiarka and Foruk can be identified as genres of folk songs that mainly found in custom ritual in most villages in Maluku in the form of: Panas Pela and Panas Gandong ceremonies (the ritual custom ceremony like a "reunion" among some villages that bound by the relationship of Pela and Gandong, etc) custom wedding ceremonies and other ceremonies such as opening and closing ceremonies of Sasi. Furthermore, according to Danandjaja (1986:141), Kapata is a kind of narrative- lyrics folksong that contains words and songs spreading orally among the particular collective society, formed traditionally and has many varieties. It is usually sung or uttered like a poem and it is situated in traditional ceremonies such as the coronation of the king, Panas Pela and Panas Gandong ceremonies or the inauguration of Baileo (the traditional house of Maluku that built up from woods). Tiarka and Foruk are still preserved until now. However, Kapata is close to extinct. It is proven by that in Central Maluku only elders or head of the custom that master and understand it who have the important roles in the society like the indigenous stakeholders or indigenous elders. Therefore this creates one big problem that directs these oral traditions into extinction which is the problem of regeneration.

\section{LITERATURE REVIEW}

\section{History of Oral Tradition}

Human's memory is one of the natural wonders of the world. One of its products is oral tradition. In the oral tradition, we recognize the history because it is a culture of old generation to the next generation. In addition, oral tradition is a medium to know history; literature works especially tale and folklore, the law in the past and other knowledge.

Foley (1997) stated that all sides in the world have been found by the ancient human. The long time ago, the modern archeology has saved the artistic and knowledge which is depended on oral tradition in several cultures as his opinion that, as in Judeo Christian Bible's said the base of oral tradition that European in medieval era has written by performing scribes, archaic Greece mirror Homer's oral style. The millennium has taught it to us; we suspect that there is a preliminary technology of communication. But, if we tell of all the truth, the oral tradition is a main source of the history as the fact of the story in several areas and the contemporary reality.

Oral tradition is the collection of information through the word of mouth from generation to generation. This has been the main vehicle for transmitting information in preliterate societies. Perhaps, it's important as well to deal with the term prehistoric societies. Furthermore, the oral traditions and expressions include of many spoken such us riddles, proverbs, folklore, tales, legends story, myths, epic songs and poems, charms, prayers, chants, songs, dramatic performances and more. Oral traditions and expressions are used to give information about the knowledge, social and culture values as well as the collective memory. Their roles are too important to keep the cultures. We can use some oral expression in communities. In many societies of the world oral tradition is used by a community to maintain the ancestor tradition.

So the study about oral tradition is a study of history which is saved the personal memorize in the past era. But it is different with a verbal study where use the literacy technology is familiar in society. One of the types of oral tradition is folklore because all about information in folklore have saved in a type of oral tradition as a history.

\section{The Problem of Endangered Tradition}

Most of the oral traditions in Indonesia are facing the reality of endangered tradition. This problem seems as a usual since it caused by some causes that spread all over provinces in Indonesia including Kapata in Central Maluku. Latupapua, et al (2012) describe that the causes are based on the reality in the field such as; the telling-process or inheritance process, either vertically or horizontally, not appropriate as it should. The inheritance process vertically is in the inheriting process in terms of intergeneration, where usually the elders who master the text of Kapata give to their youth generation. This process might have happened in a relationship between fathers and the sons or grandparents and the grandchildren. Besides, the horizontal inheritance process happens within in one particular generation that causes by the migration process, or other socio-cultural activities.

Based on the interview with all informants it is found that the mastery of Kapata only takes out in the old generations and only those who are in the part of the custom organization or usually be said as custom figures. Thus, we cannot find any young people in Maluku that can utter or sing Kapata with the sacred of Bahasa Tana. In addition, the young generation does not have any cultural awareness of 


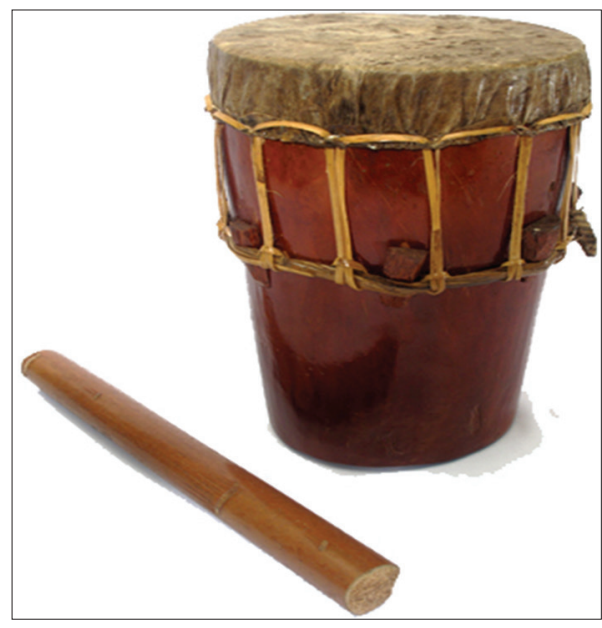

Tifa

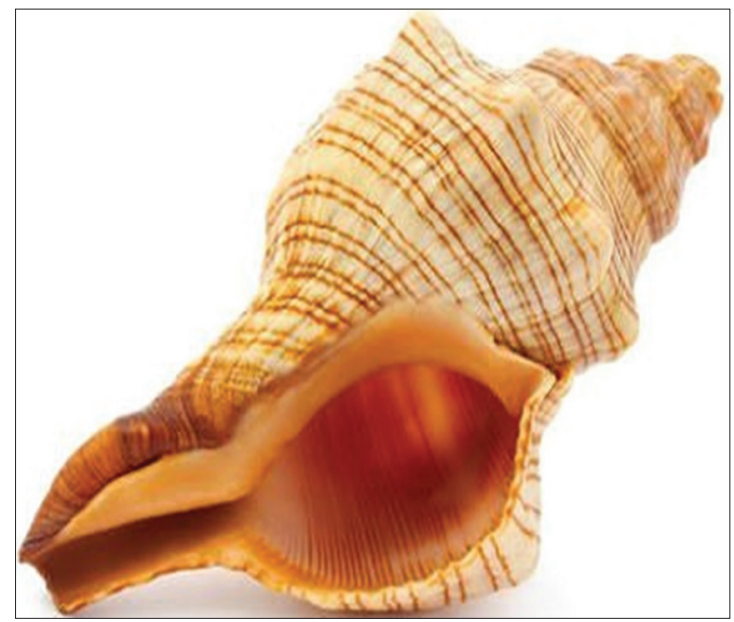

Tahuri

the importance of Kapata. According to Latupapua, some of them are not willing to learn or copy the texts of Kapata because they consider them as the holy, sacred text and belong to the ancestors, the hereditary things that shall "preserve". The action of teaching, telling, and giving to anyone is considered as forbidden that can extinct the holiness of Kapata.

The limited documentation on the text of Kapata seems to be the major problem. In fact, young generation needs to recognize it by having a reference or even the text dealing with Kapata. It is all because the object is only coming from the certain elders who are also in a limited amount. It seems like the coming researchers must conduct other researchers in order to order the documentation of Kapata, either in the texts or records.

Another factor is the effect of modernity. The inheritance process is ineffective since the young generation in one cultural community tends to focus on the modernity and its product, such as modern music, modern lifestyle and modern thought while traditional custom only plays a role as in sacred occasion, not in daily life, that cannot touch and only the elder can do it. In the end, the solution is we need a kind of oral tradition conservation not only by the researcher and the government but also form their own community. For the government, it is urgent to put Kapata and Tiarka as the parts of formal education curriculum. Besides, the art performance should be raised in order to keep it living in communities in Maluku.

\section{OBJECTIVES OF THE STUDY}

In order to meet the basic design of this study, the objectives of the research are formulated as follows: 1) to reveal the history of Kapata and the way to maintain it, 2) to map out the categories of Kapata and its function in social life, and 3) to elaborate the meaning of language expression conveyed in Kapata.

The strategy to reach these objectives is done through some steps. To reveal the historical sketch of Kapata is done through interview with traditional leader and the way to maintain it. As for the mapping out of the Kapata and its function in social life can be achieved by way of inventorying, sorting and grouping it according to its functions in Kapata ritual, which in turn will be well-altered with the Kapata's functions in social life.

The third purpose is to elaborate the meaning of language expression conveyed in Kapata. This point can be achieved by presenting Kapata's phrases. Then the phrases are interpreted in a semantic way and relate it to the worldview of Maluku society. It turns out that between their view of life and the content of the phrase in Kapata is reciprocal though difficult to prove. It's just the problem, Kapata is only practiced by the older generation, while the impressed generation started to leave and ignored it.

For the parents, Kapata's tradition is difficult to separate from their lives because the tradition has already been a part of their lives. In other words, for the older generation, Kapata is already inherent in their lives since the phrases in Kapata have a strong philosophical moral message, and are considered very useful in everyday life.

As an oral tradition, Kapata faces some problems such as a) the lack of numbers of speakers, b) the text documentation, and c) the effect of modernity. Thus, in order to preserve the Kapata, a number of things need to be done, for example, Kapata needs to be acquainted through formal education, encouraging performing, and documenting (both printing and electronic) so that Kapata can be free from the extinction.

\section{RESEARCH METHOD}

This research approaches the analysis with a descriptive qualitative method. It is to describe something based the fact. There is not any quantification procedure. According to Bryman (2008), the qualitative method is a research strategy which focused on the words than quantification in the collection and analysis of data. In addition, Sandelowski (2004) states that the qualitative method is a universal term of attitude and the strategies to conduct an inquiry which use to how human understood, have the experiences and products in the social world.

Moreover, the researchers apply some data from library study and interview. The library study is conducted dealing with some references (books, articles periodical, and journals) dealing with oral traditions of Maluku. Besides that, 
the interview is conducted by involving some informants, such as the Kapata singers, elders, and head of the custom and cultural observers in Maluku.

\section{FINDING AND DISCUSSION}

\section{General Overview of Maluku}

Geographically, Maluku province is bordering North Malu$\mathrm{ku}$ province in the North, West Papua province in the East, the East Timorese nation and the State of Australia in the South and Southeast Sulawesi and Central Sulawesi in the West.

Maluku province has an area of $712480 \mathrm{~km} 2$, comprised of approximately $92.4 \%$ sea and $7.6 \%$ inland with a number of islands reached 1,412 islands and a coastline of $10,662 \mathrm{~km}$. Since 2008, the Maluku province consists of 9 districts and 2 cities with Ambon city as the capital of Malu$\mathrm{ku}$ province. Central Maluku regency is covered three parts of the island; those are Seram island, The Banda island, and the Lease island. After Aru island, it is the second largest area in Maluku. The Regency is divided into eighteen districts: Leihitu, West Leihitu, Nusalaut, Haruku island, Salahutu, Saparua, East Saparua, north Seram, Northwest Seram, Kobi, Seti, Tehoru, Elpaputih, Telutih and Teon Nila Serua (Pattikayhattu, 1977). Generally, all parts of Central Maluku regency still maintain oral folklore as the tradition which is in form of Kapata, either in the native language or in Ambonese Malay. However, the number of people who master it is less than expected. As Latupapua (2012) found that the users of Kapata in central Maluku regency is facing to extinction due to some factors such as lack of regeneration, lack of documentation and less interest from youth.

\section{Kapata as the Oral Tradition of Maluku}

In the area of Maluku, there are two social communities namely a "nine group" and a "five group". These communities can be found in North Maluku, Central Maluku and Southeast Maluku with each different name such as Uli-Siwa and Uli-Lima in North Maluku, Pata-Siwa and Pata-Lima in Central Maluku and Ur-Siwa and Ur-Lima in Southeast Maluku (Latupeirissa, 2011). Each of these communities maintains their cultures until now in terms of traditional ceremony, behavior, and folklore as the part of social philosophy. Folklore is a cultural product in society, therefore it can be said as ethnic art and usually been preserved through the oral tradition of Kapata.

\section{The History of Kapata}

Historically, Kapata is derived from "Kapa Pata Tita". "Kapa" means a sharp top of a mountain like an index finger up to the sky". "Pata", means "being broken up definitely and cannot be changed", while "Tita" has a meaning of "the assertive words", emphatic speech. Kapa Pata Tita, it means: "Utterances firm that cannot be changed, which went up as the mountain culminating spear drawn to God", the sacred utterances and has the power undisclosed. Most of
Kapata have more than two meanings and sometimes have three meanings (Boulan/Syauta, 25). The old Kapata had a chain with the Noah Ark.: "Hua Mu Ale" contains several meanings those are: (1) "Hua Mu Ale", refers to the look of (continent) MU when God down to earth and stayed in our lives; (2) "Nete Nusan Jadi Lotemena", refers to the Land settlement expanded into large; (3) "Nunu Saku Jadi Waa Hale Muli", refers to the event when the low tide made the new Nunusaku; (4) "Sei Rewa Tanusan Jadi Yana Mena $O$ " means who knows the shaped Tanusang (is the weasel child); (5) "Sei Uli Noho Dume Rola Ika Kanike", means be ready the cluster of Noah to be clustered together "; (6) "Loyota Wai Ela Rola Mese", which refers to the big waves with powerful strength"; (7) "Singge Turu Hua Mu Ale-Luhu WAta Simolali", means submerge the original (continental) Mu." this Kapata was about the flood disaster in the Era of Noah (Soplanit, 2017).

It is found that the research of Kapata is still limited; therefore, researchers meet the difficulties in finding the related reference. So far, from some special references related to Kapata is in the writing of M.C.Boulan that has been interpreted by Saul J. M. Sjauta in 1983, with the title "Uru, Son of the Sunrise". In this writing, he explains Kapata and its existence. Essentially, Kapata or Uru reveals the events in human's history. According Christian Tamaela (1995), Kapata is the tradition of telling events or history in the past that deliver with chanting and recitation. Besides the lyrics is the native language of Maluku which is called as Bahasa Tana (Tana language) or even Ambonese Malay that used to express history, belief values and the way the people interact with ancestors. In addition, he also states that the characteristics of Kapata are (a) musical scales used; diatonic, tritonic, heptatonic and pentatonic, (b) melody used is one melody, (c) the way it is sung by responsorial style and antiphonal style, (d) the musical instrument used are Tifa and Tahuri. The following is a kind Tifa used in Kapata

Tifa is a traditional music instrument made from woods and skin of sheep, usually found in traditional dances, oral tradition and other traditional art performances. The Tahuri instrument is like in the following

Tahuri is one of the traditional musical instruments is like a shell and the way it is played by blowing the air through the hole.

\section{Definitions of Kapata}

In a document of "Kapata: Nyanyian Tradisi di Maluku" archived by The Cultural Park of Maluku - Maluku Education and Culture Department- it is explained that Kapata is folksong of tradition, it is known as the folk song which escorts the traditional dances, and uses in folk games and traditional parties. Further, Sahusilawane (2005) declares that Kapata is the song of Maluku people that sung in the native language and has a purpose to tell a story of an event or informative. In culture environment, it is widely recognized as oral tradition that categorized as oral literature, performed collectively by the groups of people in custom ceremonies or in daily life. Meanwhile, Leirissa (1999) says that Kapata or Lania is two forms of rhymes mostly recognized in Central Maluku. 
Most of the history in Central Maluku is disclosed in lyrics by using local languages. Kapata is mostly about wars while Lania is commonly about sadness things like betrayal and so on. In addition, Latupeirissa (2011) explains that as the cultural product in Maluku community is a pride that shall be preserved as the expression of local cultural values so it can be interfered by global culture. He also quotes that Kapata is in the broader context, one of cultures and arts in Maluku, which is included in the category of folk song.

\section{The Functions of Kapata}

The determination of functions of Kapata is based on the theory of oral folklore, especially in the folk song. Bascom (in Latupapua, 2012: 132) describes that commonly folklore has four main functions; (a) as the projection system, (b) as the ratification tool, (c) as the education tool for children, and (d) as the monitor and controller for its society so they will obey the rules. Kapata is also functioned as a cultural product among the communities. Furthermore, the determination is also based on folklore function. Danandjaja (1986) stated that the main function of folksong as one of the genres in oral folklore can be divided into four types: (a) recreation function, (b) spirit enhancer function for work, (c) history preservation function, and (d) social protest function. If those functions are using as the foundation to determine the functions of Kapata then the most function used in Maluku is the custom ritual function. Besides those functions, Kapata also plays a function as historic preservation or as collective history discourse. On the other hands, Tutuarima and Latupapua (2008) have their own understanding which Kapata is the history speaker of Maluku. It means that Kapata contains history that needs to inform young generations. Besides, it also contains advises to preserve our customs and ancestors' words. In the past, Kapata was sacred and only several people knew it well like those who became the members of the custom organization. In fact, nowadays, Kapata is performed (sung) widely. In its development, Kapata helps to carry out the function as the medium to enrich language and literature. This function is also important to be considered because it is related to text ability to reflect community culture so that they will use it to raise the collective awareness of culture, itself. The enrichment of language and literature refers to a revitalization process that belongs to one community due to its disability. Another function of Kapata is a social control function. It can be found in the texts of Kapata such as in Kapata Nasihat in Central Maluku from parents to children or from kings to his people. Kapata which is functioned to maintain the sanctity of customs regulations and upholding custom laws in particular community; and to preserve and maintain custom relations that have been established in a community for years. Tutuarima and Latupapua (2008) further explain that Kapata Siwalima has three main functions: a) as the historical record, b) as the medium to advise, and c) as a form of entertainment. Furthermore, Latupeirissa (2011) states that Kapata is the emotional expression which represented by symbols, the supporting factor of social norms, as the medium of communication, as the legalization of social institution and as the supporting system of communal integrity.

\section{The Value of Kapata for Cultural Life in Maluku}

Generally, Kapatas are performed not only considering the textual elements but also in the form of performing the art. Performance or resistance of Kapata is not focused on texts, but it requires other elements like musical instruments, Apapua, (a cultural term refers to "requirements" or "trimming" that becomes a must in ritual ceremonies). Materially, Apapua can be betel, nut, tobacco, and Sopi (the traditional drink in Maluku). performer, listener, dances equipment and etc. According to Sedyawati (1981), some oral literature performances are: (a) Purely literature reading, (b) Literature reading with simple movements and or limited music, (c) story presentation with dance, and (d) story presentation through scenes actualization with some players (characters) doing dialogue and dancing accompanied by music. In that explanation, it seems clear that the presentation of Kapata in Central Maluku has a tendency to move back behind between the reading of pure literature until the presentation of art performance completed by scenes, music, and dances. Kapata in ritual ceremonies involves Tifa and Apapua as the major requirements. The repetition pattern in text resistance can consider as the formula of the reader or speaker to memorize the text, mostly narrative text.

Meanwhile, in the interview with the head of Cultural Park of Maluku, he stated that Kapata is a form of the oldest music. It contains messages of oral literature or we can deliver the literature by the way we play music and also by resistance. It is not an ordinary way of communication. It brings goodness in pieces of advice. It is also can be performed by one group of family or in Central Maluku it is mentioned as Lumatauw, a communal-based community. In this place, Kapata is performed for several purposes such as for happiness and sadness occasions. The occasions in Central Maluku when it is sung are Pamoi/Souru, the ceremonies of taking wife or husband for the first time entering the Lumatauw. However, this is not complete or as ordinary as we perceive. We need betel, nut, tobacco, and Sopi to strengthen the occasion/ceremony. People who in charge to sing the Kapata, shall dress up in the traditional way. For a man, he shall only wear Cidaku, the traditional pants while women will wear clothes like Tenun or the traditional ones. Similar to Foruk in Western Southeast of Maluku and Tiarka in Southwest of Maluku, Kapa is performed with particular Rhythm and person who sings Tiarka or Foruk will wear Tenun or Basta and the fur of Cendrawasih on his or her head. Therefore we can say that Kapata is the oldest music in Maluku. The language used is in the form of ritual speech or is Tana language, which is the native language in Maluku. In the contrary, when a parent wants to give an advice to his/ her children then usually they use Kapata with Ambonese Malay, in order to give advice. This tells us that Kapata has a friction from the language used and its sacred factor. Based on the interview with the head of Cultural Park of Maluku, there is the ritual of Kapata that applies Bahasa Tana, such as Sei hale hatu lisa pei. Si lesi sou sou lesi pei o which means an oath that "who is turn the stone, the stone will in return reverse him/her. Who disobeys the oath, the oath will kill him/her". 
In modern life, Kapata is becoming the part of performing art. Then the speaker usually applies Ambonese Malay in order to make the audience understand since the modern audience also does not recognize Bahasa Tana (the mother tongue of Maluku).

As a product of language and literature, Kapata is the old music containing oral literature that becomes a tradition all over Maluku since the kingdom of Nunusaku. Patasiwa and Patalima as the custom community group in Maluku also determine the way people of Maluku perceive Kapata by using each of their different languages.

\section{The Categories of Kapata}

After conducting the research, it can be stated that there are two categories of Kapata in Saparua Island, Central Maluku. They are as follows

1. Kapata content-based

a. Kapata of History: A Kapata which tells about one particular historical event related to collective living of the owned community. Not only that, Kapata can tell about the local heroes, wars, particular thing, animals, or plants that symbolically tightly deal with community life. The texts which are included in the History of Kapata such as: Suat Kapata, Awwole Wole A Awwole, and Toma Poli-Poli.

b. Kapata of Advisory: A kind of Kapata which is sung with particular tendencies, in order to control behavior and habits of member of community who disobey the collective rules on values and ethics. This Kapata is also contained the education about customs, religions, and the good life. The examples of this Kapata are Kapata Maso Minta, Kapata Nai Cengkeh, kapata Nasehat Par Ana Cucu, Kapata Utang Budi.

c. Kapata of Worship: Kapata contains worships to ancestors, parents, exaltation for the guests. The examples are Kapata Gunung iha and Kapata Hormat Raja.

d. Kapata of recreation or solace: A kind of Kapata that contains expression to raise our spirit, giving the motivation in certain job and contain some sentences that generate the pleasure of listeners. This kinds of Kapata includes Kapata Nai Cengkeh, and Kapata Karja Mesjid,

e. Kapata of Affection: Kapata contains a love story or to express affection among youth. The texts of Kapata including Kapata Inga Cewe.

2. Place and situation-based

a. Customary Kapata; A Kapata that is performed or uttered in a ritual ceremony.

b. Regular Kapata; A Kapata that is performed or uttered in family gathering, marriage and so on.

Furthermore, below are some Kapatas which related to oral tradition texts in Saparua island, Central Maluku that usually perform or sing in several customs ceremonies:

1. Kapata of Advisory

Ami mahai dunya tine (We live in this world)

Sei iyoso mai, otarimalo mai (Who makes goodness, will get goodness)

Sei iyoso ahia otarimalo ahia le (Who makes badness, will get badness)
Sei mahai dunia tine (Who lives in this world)

Ku moke waso mae iti mala aherate (If he/she makes goodness)

Supu mae titil le e, ap mutuwao (Will get a return in heaven)

Su u oi taano pisara am le (This is an oath of the ancestors that cannot be forgotten)

This Kapata is from Nolloth Village, Central Maluku. It contains the meanings of the true family when parents and elders of one big family gather and plan on one big occasion whether it is marriage or reunion. Through this Kapata the children will gain the pieces of advice for their future.

2. Kapata Inga Cewe

Malakao sei (I am moarning how I can see you)

Sei amboina e (You, who are in Ambon)

Ami malwa sei pame seminia (I want to meet my girlfriend)

Manuhata tura (But I cannot)

Koku lima yapakali (I regret, put five fingers on the head)

This Kapata is from Ullath Village. It is categorized as Kapata of Affection. The meaning of this kapata is to tell us about the regretness of a man when he cannot meet his lover. 3. Kapata Bakar obor Pattimura

Rombongan adat dari negeri Beinusa (Custom group of Tuhaha)

Datang kawali api Pattimura e (Come to guard the fire of Pattimura)

Api semangat perjuangan bangsa $e$ (The fire of the struggle of the nation)

Sioh dari dulu sampe la sekarang e (From the past until now)

Inilah rombongan adat dari negeri Beinusa e (Here is the custom group of Tuhaha)

Inilah rombongan adat dari negeri Beinusa e (Here is the custom group of Tuhaha)

This Kapata is from Tuhaha village. It is uttered by Kapata singer on the occasion of Pattimura's annual ceremony/before taking the torch, the singer will utter this Kapata as the remembrance of Pattimura. Especially in this kind of Kapata is expressed in Ambonese Malay, comparing with others are expressed in Tana language.

4. Kapata Kerja esjid

Sumba sumba Upu, Upu Tukano Hussanlalua (Praise, praise to the lord. The 12 lords of custom)

Mae ihiti masitte huhunyo etine (Come all friends)

Mae mae ulahanno ihitilo (Come, come all friends)

Lotto wau Upu tukang adat (The lord of custom has already on the edge of the mosque)

Sepamara Samai e (The Custom name of Tuahuns Family)

Naani taulo lotto masitte huhunyo etine naalo (Put it on the edge of the mosque)

Naa nipen naalo supaya adat masitte hee nupela (To nail it properly thus the custom ceremony is accomplished)

This Kapata is uttered in custom ceremony for renovating the mosque. It is usually uttered by the udstaz/imam (moslem leader). 
Based on the explanation above, Kapata can be seen from two aspects; function and category. Aspects of functions include a) historical sketch of the society, b) means of advisory, c) form of entertainment, d) the projection system, e) ratification tool, f) education for children, g) social control, and h) the enrichment of language and literature of Maluku. Furthermore, the Kapata can be categorized into two: content-based and b) conditional-based.

\section{CONCLUSION}

Based on the discussion, this research has addressed at least three important aspects of the research objectives of each of the historical sketch of Kapata. The Kapata is a hereditary cultural heritage that is believed to have a way of life aspect of the people of Maluku. Because Kapata is believed to have an important aspect of life, so it must be maintained and preserved. One of the most effective methods is through education. Furthermore, Kapata can be categorized as a social adhesive and hence its function creates a harmony in social life. This can be proved by the attention of the people to keep maintaining the implementation of Kapata tradition as part of the cultural ritual.

The society of Maluku believes that Kapata has the glue of society and brings prosperity to this life. As a result, Kapata can be interpreted linguistically from the form of expression. Kapata has a beautiful phrase even though the phrases of language in Kapata are often difficult to understand. Kapata is an oral tradition. It has a role in reordering the past because it contains messages from the past to present time and these messages become a key element in maintaining history.

As a cultural heritage, Kapata remains highly regarded for the people of Maluku so it must deserves to be preserved to keep out of extinction. The extinction of a cultural heritage is an invaluable loss for future generations. Thus Kapata culture stakeholders must have a moral responsibility to keep Kapata inherited for future generations. The practical significance of this research is raising awareness of how important the cultural aspect is preserved and passed on to the next generation.

\section{REFERENCES}

Bryman, A. (2008). Social Research Methods (3 ${ }^{\text {rd }}$ ed.). Oxford: Oxford University Press, USA.
Danandjaja, J. (1986). Folklor Indonesia. Jakarta: Grafiti Press.

Foley, William (1997). Anthropological Linguistics: an Introduction. Oxford: Basil Blackwell

Latupapua, F. E. et al. (2012). Kapata, Sastra Lisan di Malu$k u$ Tengah. Balai Pengkajian Nilai Budaya Ambon.

Latupeirissa, N. A. (2011). Kapata dalam Kajian Semiotika menurut Teori Trikotomi Peirce. Tesis pada Program Pascasarjana Ilmu Seni Musik, Institut Seni Indonesia, Yogyakarta.

Leirissa R.Z,et.al (1999). Sejarah Kebudayaan Maluku. Jakarta: Direktorat Jenderal Kebudayaan Departemen Pendidikan dan Kebudayaan RI

Pattikayhattu J.A., (1977). Sejarah Daerah Maluku, Proyek IDKD Dep. Pendidikan dan Kebudayaan 1976/1977. Jakarta: Departemen Pendidikan dan Kebudayaan.

Rahman, Fathu. (2017). The Revival of Local Fairy tales for Children Education. Theory and Practice in language Studies $<$ http:/www.academypublication.com/> DOI: ttp://dx. doi.org/10.17507/tpls.0705.02 Vol.7, No 5 (2017)

Sahusilawane, F. (2005). Cerita-Cerita Tua Berlatar Belakang Sejarah dari Pulau Seram. Ambon: Balai Kajian Sejarah dan Nilai Tradisional Provinsi Maluku dan Maluku Utara.

Sandelowski, M. (2004). Using Qualitative Research. Qualitative Health Research, 14, 1366-1386. <https://doi. org/10.1177/1049732304269672>.

Sedyawati, E. (1981). Pertumbuhan Seni Pertunjukan. Bandung: STSI Press.

Soplanit, Julian. (2011). Sejarah Alifuru. $<$ http://juliansoplanit.blogspot.co.id/2011/03/sejarah-alifuru.html $>$ Retrieved October 9, 2017.

Surya, Waode et.al (2017). Folktale from England to Toraja. Imperial Journal of Interdisciplinary Research (IJIR). Vol-3, Issue-7, 2017 ISSN: 2454-1362, Retrieve online from: <https://www.onlinejournal.in/IJIRV3I7/084.pdf $>$.

Teeuw, A. (1994). Indonesia Antara Kelisanan dan Keberaksaraan. Jakarta: Pustaka Jaya

Tutuarima, F \& Latupapua, F. E. (2008). Kapata sebagai Penutur Sejarah Masyarakat Maluku (Kajian Hermeneutik terhadap Kapata Siwalima dari Negeri Soahuku, Maluku Tengah). Laporan Penelitian Dosen Muda DIPA Universitas Pattimura.

Vansina, J. (1985). Oral Tradition as History. Madison: University of Wisconsin Press. 